\title{
The Trials and Tribulations of Two Historians: Adjudicating Responsibility for Pollution and Personal Harm
}

\author{
DAVID ROSNER and GERALD MARKOWITZ*
}

\begin{abstract}
Why Historians in the Courtroom?
The origins of historians' role in toxic tort cases are rooted in the fundamental transformation of Americans' health beliefs during the course of the past half century. For much of the first fifty years of the twentieth century the dominant concerns of most Americans were a series of diseases that could be linked directly to specific bacteria or viruses, or, alternatively, for the industrial worker, to specific acute exposures to a toxin. Generally, the symptoms that affected the individual were acute and specific agents - whether bacteriological, viral or chemical-which could be identified in the laboratory using increasingly sophisticated technologies. Tuberculosis, for example, could be understood to be "caused" by a bacterium, while the palsies, tremors, or wrist-drop of industrial workers could be identified as "caused" by exposures to lead in battery plants or other industrial settings.

But, during the course of the twentieth century, basic public health measures like improved sanitation, pure water supply, street cleaning, and nutrition among others began to have a dramatic impact on the health of Americans. Lower rates of infant mortality, longer life spans and a decline in the importance of infectious disease as a cause of death fundamentally altered the epidemiological experience. Further, with the development of sulpha drugs, antibiotics and effective vaccines against polio and other childhood diseases in the middle decades of the century, many Americans believed that the danger of infectious disease was passing. Chronic conditions such as heart disease, cancer and stroke replaced tuberculosis and other infectious diseases as the major killers of Americans. By the 1970s, many in the public health community were seeking a different model for understanding what caused chronic disease.

The advent of a vibrant environmental movement fed a new paradigm for understanding disease. Chronic conditions were increasingly seen as being rooted in the industrial world in which Americans now lived. The emergence of the country as the predominant

(C) David Rosner and Gerald Markowitz 2009

*David Rosner is Ronald Lauterstein Professor of
Sociomedical Sciences and History at Columbia
University. He is also Co-Director of the Center for
the History and Ethics of Public Health at Columbia's
Mailman School of Public Health, 722 West 168th
Street, Suite 934, New York, NY 10032, USA;
e-mail: dr289@columbia.edu
Gerald Markowitz is University Distinguished Professor
of History at John Jay College, and CUNY Graduate

Center, City University of New York; e-mail: gmarkowitz@jjay.cuny.edu

Originally presented by David Rosner as the Edward and Amalie Kass Lecture, Wellcome Trust Centre for the History of Medicine at University College London, 10 Dec. 2007. An earlier draft of this paper was presented at the Coronado Conference on Integrity in Science, Bretton Woods, New Hampshire, 4 May 2007, and will appear in Law and Contemporary Problems, Winter 2009, 72 (1).
\end{abstract}




\section{David Rosner and Gerald Markowitz}

world economic and military power in the years after the Second World War fed a growing uneasiness. For some in the public health community, disease was increasingly perceived as a signal of the inequalities and injustices brought about by rampant commercialization of medicine, the poor distribution of services and the greed of what some deemed the "medical-industrial complex".

In the late 1970s and 1980s, disastrous examples of the impact of industry on the quality of life and the health of populations brought to national attention the negative effects of industrial society on American health. Homes in Love Canal, New York, a community just outside Buffalo, were found to be polluted by the waste products of the Hooker Chemical Company. A whole community of lower-middle-class homeowners had to leave their residences as the contents of leaking barrels and waste pits slowly bubbled up into basements and backyards; at Three Mile Island, Pennsylvania, a nuclear plant nearly went into meltdown just at the time when a film called The China syndrome made Americans all too aware of the pitfalls of nuclear energy. In Times Beach, Missouri, an entire community was evacuated and huge areas of the town were roped off after it was discovered that dioxins and polychlorinated biphenyls (PCBs), known human carcinogens, had polluted the streets. In Bhopal, India, thousands of poor people were killed, blinded and maimed by an explosion of a Union Carbide plant. Unlike the infectious diseases of previous eras-or even AIDS, SARS and anthrax of the more recent past - the chronic diseases that frightened most Americans could not easily be linked to an exposure to a specific biological agent. Rather, the existing models for disease causation could only inexactly explain the complex pathways and mechanisms that led to a cancer years and often decades after exposure.

The growing awareness of the dangers of industrial pollution, and industrial products more generally, fed a widespread sense that the killer diseases of greatest concerncancers-were produced by a variety of consumer goods that were now a mainstay of American life. Cigarettes, plastic bottles, corporate promotion of fatty foods and sugarladen soft drinks, to name but a few, were no longer seen as symbols of the good life but increasingly as responsible for epidemics of lung cancers, heart disease, diabetes, obesity and other chronic conditions. More and more people argued that the ways we die and the diseases that afflict us are, in large measure, reflections of the world we build and the environments we create. Whether they be the slums and crowded housing of the nineteenth century that led to massive outbreaks of infectious diseases and tuberculosis, or the environmental assaults or industrial toxins that are now associated with the cancers and other chronic diseases that are major killers today, disease and the ways we deal with it can be understood as a reflection of social organization, values and ideals. In the last decades of the twentieth century and the beginning of the twenty-first, scientists, politicians, community activists, consumer organizations and government officials have been engaged in an on-going debate over the role of environmental pollutants in producing disease and other conditions that affect human reproduction, intelligence, and behaviour.

The authors have been at the centre of several major environmental and occupational law suits in which the historical record has been crucial in assessing the responsibility of industry for these new harms. This paper explores our role as historians in these legal actions and the response of industry to our participation. 


\section{The Trials and Tribulations of Two Historians}

\section{Trolling for Historians}

Two years ago, as we were sitting our office working, one of us received an odd e-mail. "Dear Dr Rosner," it began:

I am writing to introduce you to the Round Table Group, and to notify you of a short-term consulting opportunity which may be of interest. Our client is seeking an historian, highly credentialed, at a prestigious university to perform some historical research, and instruct a lay jury about what was known about a particular occupational hazard (lead paint contamination) in 1950 to 1980.

The letter went on to explain how the historian they sought "need not be a subject matter expert" but need only be a "good communicator" who could "easily communicate a story to a jury". The e-mail continued in some detail, explaining how the process would work: if David were interested, he could send in his resume', a brief explanation of his expertise, and a statement of his consulting fee. After consulting with their industry client, he would be set up on a conference call to "determine if there is mutual interest in going forward". The note continued by informing him about the consulting group: it was a consortium of "several thousand professors" in "management, law, medicine, science, computer science, education, engineering, economics, and other disciplines who make themselves available to law firms and companies who are clients of the Round Table Group." Obviously, historians were a new addition to their stable of experts. What was amusing, if that is the right word, was that RTG was searching for an expert to testify on behalf of companies in a lead trial and at that very moment both of us were preparing to testify in a major lead trial on behalf of the state of Rhode Island. ${ }^{2}$ We had written a book on the lead and vinyl industries based on documents we had uncovered through legal proceedings. ${ }^{3}$ The documents, an affidavit we wrote and the book had all become part of a landmark case in which Rhode Island's Attorney General, with the support of Motley Rice, the plaintiffs' law firm, was suing the lead pigment manufacturers to get them to remove lead paint from hundreds of thousands of buildings in the state. It appeared that the lead industry was searching for someone to testify against us.

During the past few years historians have been brought into legal cases in unprecedented numbers. As the courts have tried to adjudicate responsibility for environmental and occupational diseases, history has played a more and more central role in decisions that affect the cases themselves and social policy regarding risk. In suits over tobaccorelated diseases, asbestosis, radiation, and other toxic substances, more and more historians of technology and science, social history and public health are being brought to provide testimony aimed at assessing responsibility for damages that have arisen years, sometimes decades, after exposure. The basic questions asked are those we became familiar with during the Watergate hearings: who knew what about specific toxins and

\footnotetext{
${ }^{1}$ See e-mail: Barb Noverini to David Rosner, 'RTG Consulting Opportunity for an Academic Historian', 13 Jan. 2005. See also http://www. roundtablegroup.com/litigation/experts.cfm (accessed 27 Nov. 2008) the website for their experts in which it is noted that their academic consultants now number over 65,000 , including university deans and prominent professors.
}

\footnotetext{
${ }^{2}$ State v. Lead Indus. Ass' n, 2007 R.I. Super. LEXIS 32, 2-11, 318-19 (26 Feb. 2007).

${ }^{3}$ Gerald Markowitz and David Rosner, Deceit and denial: the deadly politics of industrial pollution, Berkeley, University of California Press; and New York, Milbank Memorial Fund, 2002.
} 


\section{David Rosner and Gerald Markowitz}

when did they know it? Did industry understand that specific substances could cause disease? If so, when did they learn of the dangers and when did they begin to warn their workers or the consumers of their products that they were at risk?

As the role of the historian has expanded, so too has the controversy surrounding their participation. At the annual meeting of the American Association for the History of Medicine, traditionally collegial sub-specialists, a panel on the history of childhood diseases ended up in a shouting match after a respected historian who at one time or another had been a paid consultant for the tobacco, asbestos, soft drink and lead industries, presented a paper arguing that the lead industry had done nothing wrong before the 1950s and that, in any case, the problem of childhood lead poisoning was vastly overblown. ${ }^{4}$ During the conference the halls were abuzz with gossip and amazement and it soon became apparent that many more members had been testifying on behalf of industry. A former president of the Association and professor of medicine and history had been testifying and writing affidavits for the tobacco industry for nearly fifteen years; another professor of medicine and history had worked for both the tobacco industry and the lead industry throughout the 1990s; less well known historians had been recruited by big tobacco and others. One historian gathered the names of over thirty colleagues who have worked for the tobacco industry alone. ${ }^{5}$

A relative handful of historians have testified against industry. Allan Brandt at Harvard worked for the federal government on a suit against the tobacco companies. ${ }^{6}$ Robert Proctor has worked on the same suit and has, in the past, worked for women damaged by radiation experiments at Vanderbilt University. David Rothman has worked on the Vanderbilt case as well. The industrial hygienists David Ozonoff and Barry Castleman have weighed in offering historical documentation on behalf of workers injured by exposure to asbestos, developing sensitive historical arguments about the culpability of Johns Manville and other asbestos manufacturers. ${ }^{7}$ We have written books that detail the ways that silicosis, lead and vinyl production have undermined workers' and consumers' health, and we have testified and been deposed in silicosis, lead and vinyl chloride cases. ${ }^{8}$ All of us have gone through our own internal decision making

\footnotetext{
${ }^{4}$ Patricia Cohen, 'History for hire in industry lawsuits', New York Times, 14 June 2003, pp. B-7-9; Significantly, the origins of historians entering into liability cases originated with the defence themselves. Robert Proctor reviewed the efforts of the tobacco industry to recruit historians to testify for the industry as early as 1987. One of the first was "a professor of history at Ohio State University and section director for Project Cosmic, Philip Morris's secret effort (1987-1993) to produce 'an international network of scientists and historians' to write histories casting the industry in a favorable light", see Robert Proctor, "'Everyone knew but no one had proof": tobacco industry use of medical history expertise in US courts, 1990-2002', 'TC Online', 28 Oct. 2004, (http:// tobaccocontrol.bmj.com/cgi/content/full/15/supp_ 4/iv117); Expert Disclosure of John C Burnham, Cipollone v. Liggett Group, Inc., et al. In the
}

Cipollone Civil Action No. 83-2864SA, 1986 (est.), pp. 2-3. Bates No. 2024941548-1551. http:// tobaccodocuments.org/pm/2024941548-1551.html (accessed 27 Nov. 2008).

${ }^{5}$ Proctor, op. cit., note 4 above.

${ }^{6}$ Allan M Brandt, The cigarette century: the rise, fall, and deadly persistence of the product that defined America, New York, Basic Books, 2007.

${ }^{7}$ D Ozonoff, 'Failed warnings: asbestos-related disease and industrial medicine', in Ronald Bayer (ed.), The health and safety of workers: case studies in the politics of professional responsibility, Oxford University Press, 1988, pp. 139-218; and Barry I Castleman, Asbestos: medical and legal aspects, 5th ed., New York, Aspen, 2005.

${ }^{8}$ See Markowitz and Rosner, op. cit., note 3 above, and also note 16 below. 


\section{The Trials and Tribulations of Two Historians}

process in deciding whether or not to work for those injured by industries, institutions or products. All have determined in one way or another that using our skills in this way was important and made history more meaningful.

\section{A Look Back at Historians in Court}

Beginning in the late 1940s with the landmark case Brown v. Board of Education, expert historical testimony has been employed increasingly in courts of law. In recent decades, historians have testified in a variety of civil cases: claims brought under the Voting Rights Act of 1965, water rights disputes, suits against schools for teaching "creation science" in classrooms, sex discrimination lawsuits such as EEOC v. Sears (1986), libel cases brought by Holocaust deniers, and, perhaps most famously, suits against tobacco and lead industries. The prominence of historians in these cases has led members of the profession, and especially those who have served as expert witnesses, to reflect in various articles on how expert testimony has affected the practice of history. First and foremost, these articles have addressed that perennial "objectivity question", and specifically, the issue of whether representing one side in the adversarial process has compromised the historian's duty to seek historical truth. Have historians in these cases been pressured to distort the facts in order to win?

The "objectivity question", an issue that has persistently dogged historians in general and legal cases in particular, has led to numerous exchanges in professional journals and newsletters over the past few years. Brian Martin, a historian working at History Associates Incorporated, a "consulting [service] in historical research and writing, litigation research, and archives and records management", whose clients have included "more than 300 corporations, government agencies, and professional and nonprofit organizations worldwide", has argued in the Newsletter of the Organization of American Historians that historians can remain as dispassionate observers of historical truth despite their participation in legal proceedings. In fact, he argues that the need of the legal system to uncover data both useful as well as harmful to a client demands this dispassionate objectivity from historians working as consultants. ${ }^{10}$

The idea that the courtroom corrupts the practice of history generally rests on the assumption that epistemological processes of history and litigation contradict one another so as to make it impossible to remain faithful to one while becoming engaged in the second. In 'Are expert witnesses whores? Reflections on objectivity in scholarship and expert witnessing', J Morgan Kousser, a Cal Tech historian who has testified in numerous voting rights cases, describes this ostensible clash of knowledge-production cultures:

The image of the lonely scholar, or to modernize it a bit, of the lonely research team, seeking truth by applying their open but careful minds to the appropriate evidence, is pervasive among social

\footnotetext{
${ }^{9}$ History Associates Website, http://www. historyassociates.com/ (accessed 27 Nov. 2008).

${ }^{10}$ Brian W Martin, 'Working with lawyers: a historian's perspective', OAH Newsletter, May 2002,
}

30, available at: http://www.oah.org/pubs/nl/ 2002may/Martin.html (accessed 27 Nov. 2008). 


\section{David Rosner and Gerald Markowitz}

scientists and humanists. Scholars may make mistakes ... but they don't, goes this standard stereotype, purposely distort. ${ }^{11}$

In contrast, the courtroom is an adversarial environment, notes Kousser, and the lawyer is responsible "simultaneously to maximize the chances of his or her own client ... [A]n Invisible Hand guides the process toward the maximum production of truth". ${ }^{2}$

For many, the way the courts, and lawyers in particular, use evidence and historical events undermines the historian's role. David Rothman, himself an expert witness, argues that the historian should be involved in using his or her expertise in trials if the cause is just and the impact significant but the historian should recognize that whatever he or she does in the courtroom is something other than history. Arguing from his experience in the Vanderbilt radiation cases, Rothman observes that lawyers frame narrow questions for the historian to answer and this ultimately undermines their autonomy and their ability to cast a wide net, to contextualize or to place events in a deeper historical context. He argues that when he testified "the integrity and soundness of [his] testimony remained" and that "the added research that I conducted did not alter any of the findings that I had offered in my reports and depositions in the Vanderbilt case. To focus an inquiry does not distort the results." After all, as Kousser argued elsewhere, expert witnesses "dare not contradict their prior positions [for] if they did, opposing counsel would immediately pounce on them". ${ }^{13}$

Nor is it correct to say that "expert witnesses are too committed to their side of the case to remain objective [for] historians are no more or less 'objective' in the courtroom than they are in the lecture hall or in print". Yet, because of the constricted nature of work in the courtroom a distinction needs to be made: "To enter the courtroom is to do many things, but it is not to do history. The essential attributes that we treasure most about historical inquiry have to be left outside the door. The scope of analysis is narrowed, the imagination is constrained, and the curiosity, curtailed."14

Yet these critiques of history in the courtroom can be applied as well to all other disciplines and individuals who serve as expert witnesses. Lawyers faced with uncomfortable historical data (such as minutes of meetings where the toxicity of a substance is discussed or documents that present evidence of industry knowledge of harm done) argue that history is an implicitly subjective discipline, one which is lacking in a methodology that allows for replication of results or even a test of reliability. Some have argued that it is not a science, that historians are incapable of providing "expert" opinion on a par with the biologist, the chemist or even the doctor. Yet, for the most part, such arguments have fallen on deaf ears since similar arguments could be brought against physicians whose clinical methodologies are often the very subject of court cases, and other sciences where Popperian notions of falsification and reliability are rarely if ever tested. As John Neuenschwander, a judge and historian has written, "Historians who testify are often presented by their lawyers as paragons of objectivity, however, judges ... seem to realize

\footnotetext{
${ }^{11}$ J Morgan Kousser, 'Are expert witnesses whores? Reflections on objectivity in scholarship and expert witnessing', The Public Historian, 1984, 6 (1): $5-19$.

12 Ibid., p. 15.
} 


\section{The Trials and Tribulations of Two Historians}

that there is no such thing as true objectivity. Ultimately, the bench looks for the same qualities that are required of all experts: appropriate specialization, thorough research, and conclusions that are well supported by the record." In other words, it is up to the judge and jury to decide on the reliability of the witness, just as it is with other experts from other fields. ${ }^{15}$

\section{The Dark Side of Industry-Historian Relations}

The courts are both an important and a troubling arena into which historians are being thrust. For the most part, academic historians are anxious about being in the limelight. Often bookish by nature, most have been brought up in a professional culture that reinforces individual research, alone in archives that few others have ever visited. While the image of the monastic scholar is certainly overblown and parodied in the media, film and popular culture for life-long dedication to issues that few care about, there is a grain of truth in such stereotypes. Scholars in the humanities and some social sciences often prize individual effort on what many outside academia might consider arcane subjects. Also, in the wider world of academic historians there is a tendency to look with a certain sceptical eye at those who popularize complex historical events. In part, this reticence is due to a concern that such popular renderings are necessarily superficial. But there is also an element of jealousy involved, as popularizers reach a public unimaginable to the academic historian, many of whom write for tiny audiences numbering in the tens, or hundreds.

In many cases historians are recruited because of their highly specialized knowledge. This was certainly true when we first became involved in silicosis cases following the publication of our book, Deadly dust: silicosis and the politics of occupational disease in twentieth-century America. ${ }^{16}$ As historians of occupational disease, we had stumbled onto silicosis, a disabling lung condition caused by the inhalation of silica dust-finely ground sand-that had struck down thousands of workers in the decades before the Second World War, being labelled "this king of occupational diseases" by commentators at the time. We had written the book with no knowledge that the disease was still of great concern, seeing our work as an exercise that could illuminate the ways that discovery of disease was rooted in very special historical circumstances of economic depression, social dislocation and medical change. Interestingly, we had traced the heated debates around silicosis that occurred among workers, organized labour, government and a series of industries such as foundries, steel mills, construction, and sandblasting in which silica sand was used and workers exposed. Shortly after the publication of the book we learned from our editor at Princeton that the hardcover version was in short supply and that they

\footnotetext{
15 John A Neuenschwander, 'Historians as expert witnesses: the view from the bench', OAH Newsletter, Aug. 2002, 30, available at: http://www.oah. org/pubs/nt/2002aug/neuenschwander.html (accessed 27 Nov. 2008).

${ }^{16}$ David Rosner and Gerald Markowitz, Deadly dust: silicosis and the politics of occupational disease
}

in twentieth-century America, Princeton University Press, 1991, recently republished and updated as Deadly dust: silicosis and the on-going struggle for workers' health, Ann Arbor, University of Michigan Press, 2005. 


\section{David Rosner and Gerald Markowitz}

were considering a paperback edition. How, we asked, could such a book with a seemingly select audience be out of stock so soon?

After quick investigation, the press discovered that, contrary to our assumption, the book was not being bought by large numbers of labour or other historians but, rather, by law firms. Soon, we found ourselves being called by law firms from all over the country who wanted to consult with us about their cases. It appeared that workers in a host of industries, primarily in Texas, Louisiana, and other Gulf states, were still coming down with silicosis and were suing a variety of sand suppliers and equipment manufacturers. At first, we were hesitant to get involved. It seemed repellent to us to appear at depositions, testify in court, and subject ourselves to possible pressures to meet the demands of court cases. We were scholars, not interested parties, removed from the events of the day by training and inclination, and scholars were not in the business of testifying, at least in court. Memories of the contentiousness that affected the historical profession following the engagement of two of our friends on different sides of the Sears case in the 1980s made us especially wary of getting involved.

Yet, after one lawyer came to New York and presented the haunting story of one of her clients, we changed our minds. She told of her client, a 34-year-old Mexican worker who had been told of a relatively lucrative job in the oil fields of West Texas. A huge oil company had contracted to have sandblasters clean out old oil storage tanks in the 1970s, following the OPEC oil crisis when West Texas crude was once again in demand. Mexican workers had come to the area around Odessa, Texas. Contractors had given them paper $3 \mathrm{M}$ masks and a sandblasting unit and had them enter into small enclosed tanks and blast sand at the layers of tar and oil that had accumulated over the previous years and decades. Not surprisingly, workers began to die, for the tiny particles of sand that permeated their lungs caused fibrosis which rendered them unable to breathe.

These cases, it appeared, would never have come to light had it not been for the decision of a local physician to find out why so many of the migrant workers he was seeing were dying from a lung condition whose symptoms mimicked tuberculosis. Workers were coming to him as perhaps the only physician in town willing to see them, complaining of an inability to take a deep breath, spitting, weight loss and extreme fatigue. Some told him of other friends of theirs who had gone back to Mexico to die slow, horrible deaths at home. Others simply succumbed in Odessa.

It was clear why our book could be so important to these workers and their families. We were told that in court case after court case, lawyers for the sand producers, equipment manufacturers and the companies that had employed these men had been arguing successfully that since "no one" had ever heard of silicosis, "no one" could be held accountable for a disease that was unexpectedly killing workers. Our book was a direct contradiction to the central tenet of these defence tactics: we documented in minute detail what was known about the disease and the industry's attempts to dismiss silicosis as a "curiosity". We documented the "dusty trade's" knowledge about and concern with silicosis in the 1920s, 1930s and 1940s even as they attempted to avoid responsibility for workers who were dying from exposure to silica. We agreed to become "expert witnesses" in two cases.

We will never forget our first deposition. Each of us was deposed for several days by about twenty lawyers representing some of the largest corporations in the country at the 


\section{The Trials and Tribulations of Two Historians}

Plaza Hotel in New York. One lawyer had told us that a deposition was just like a PhD oral exam, something akin to a seminar where we would provide information and engage in serious academic issues. Such a seminar could not last more than a few hours, we believed. But such was not to be the case. Each of us was grilled for several days from nine in the morning to five at night with defendants' lawyers going into virtually every aspect of our book, from its footnotes to its index and pagination. What were our sources for the statement on, for example, page 45? Could we provide the document that was the basis for the statement on another page? Was one reference to a point enough to "prove" that this quote represented a fair cross-section of the population? What were our credentials? How did we work together? Did we walk to work together? Where did we live? What languages were spoken in my neighbourhood? Who did we vote for in the last election? Which magazines did we read? What organizations did we belong to?

Virtually no aspect of our academic or personal lives was off-bounds in the free-for-all that seemed to have no end. As the deposition went on we realized the enormous stakes that were involved. A score of companies faced by potentially thousands of lawsuits had hired lawyers to undermine our credibility lest we ever got to the witness stand and were able to speak to a jury. We also began to understand the stakes involved for the families, many of whom had no source of income to replace the meagre wages that their husbands had earned while working themselves to death.

About a year later David was finally called upon to testify in that case. In the courtroom sat the worker and his family-he was attached to an air hose connected to a portable air tank, and his wife and children surrounded him. David was on the stand for the entire morning. Numerous objections and challenges were made by the defence attorney as he sought to undermine our book and David's testimony on behalf of the client. Sentences were picked out of long monologues that David had given in attempts to answer complex questions with answers longer than "yes" or "no". It was a strange experience.

It was gratifying that by lunchtime, David's testimony seemed to have made a deep impression on some of the company lawyers. A number of the defendants came slowly to the plaintiff's table and sought to "settle" their responsibility for damages, opting to pay something to the client rather than risk a jury verdict that might cost them much, much more.

It was a victory of sorts, but for David, the most meaningful moment came during a recess when he had the chance to speak with the worker who had been made ill by the silica dust and his family. This migrant told of his life, his family and his children. His wife invited David to dinner at their home. It was clear that the testimony made on his behalf was extremely important to the children who kept thanking David for coming to Texas "for their father". They had translated for him throughout David's testimony and they conveyed his deep gratitude. The testimony had affirmed the man's experience and let his own family know that his experience was meaningful. This alone, it seemed, was worth the extraordinary pain that the day in court had cost him. We cannot convey how moving this occasion was. It made us realize that history does matter.

That first experience was searing. But, in coming years we found that we became less and less fearful of the deposition and courtroom process, and more and more convinced 


\section{David Rosner and Gerald Markowitz}

that our particular skill in writing history was making a real difference for many people throughout the country.

One singularly interesting and rewarding turn of events was the public "rediscovery" of the disease by the United States Department of Labor's Occupational Safety and Health Administration (OSHA), the Mine Safety and Health Administration (MSHA), and the National Institute of Occupational Safety and Health (NIOSH). In 1997 we were invited to a National Silicosis Conference organized by these three agencies and shortly afterwards Robert Reich, the Secretary of Labor, announced that silicosis was a "target" disease for the administration who sought to eliminate it by the turn of the new century. Finally, after decades of stalling, in-door sandblasting (a practice that we had identified in our book as having been of particular concern) has largely been abandoned. We began to realize that there was a world that appreciated history for the ways it could really help people.

It is clear that lawyers have had some trouble trying to work out how to address historical data and the historians who develop materials. By 2002, our book had become widely distributed and the documents we had found were now commonly entering into law suits against companies, particularly in the southern states. We had ceased to participate in most cases because we had developed fairly exacting standards for participation: refusing to stray away from the documentary record or to shape our arguments around particular cases, refusing to take any case where we were asked to sign confidentiality agreements, or to refrain from publishing if we saw fit, or if denied access to all historical data produced during discovery. Yet, as outlined above, we had played a role in the rediscovery of silicosis as a serious problem.

Initially, we felt quite protected from any outside criticism by the unusual fact that we were well-recognized scholars who were tenured at major universities. Further, our work had been widely reviewed in medical, science, history and other journals and almost universally been hailed for the research and restraint with which we presented our material. Science, perhaps the leading publication of its kind, had called it a "paradigmatic tale", $J A M A$, the New England Journal of Medicine, as well as the leading historical journals such as the Journal of American History and the American Historical Review, had all hailed it. True, Deadly dust was critical of many of industry's actions, but the fact that we stuck close to our sources and almost always "let the documentary evidence speak for itself" gave us reason to think that our reputations as scholars were secure among the academic community that we generally related to. We had both spoken extensively about silicosis and other occupational diseases in front of historians, medical personnel and others in Ivy League and many major research universities to general praise for opening up new vistas of historical inquiry.

For most of the 1990s the attempts to undermine our work were done in depositions, generally private meetings where we could defend our reputations by presenting the documents we had uncovered. While the depositions were trying, in fact we had the materials available and often provided thousands of pages to defence attorneys. But that began to change shortly after the turn of the new century. The first shot across the bow occurred at a meeting of lawyers sponsored by LexisNexis in Washington at which Nathan Schachtman, an attorney with McCarter \& English in Philadelphia, gave a lengthy address attacking us and our book. In Mealey's Litigation Report: Silica, published in 


\section{The Trials and Tribulations of Two Historians}

2003, he castigated us for writing a "jeremiad" that "resonates to the passions and prejudices of the last century". He took us to task for our "prejudice" that "silicosis results from the valuation of profits over people" and for not pointing out that in Communist countries silicosis rates were much higher. "They fairly consistently excuse or justify the actions of labor ... They excoriate the motives and actions of industry ...". Later on the same page, Schachtman argued that our "thesis ignores the practical ... problem of motivating or mandating workers to take appropriate measures to protect themselves". ${ }^{17}$ Schachtman saw no problem with accusing us of sloppy scholarship, arguing that we are little more than propagandists, all in the first page of his piece. But his true agenda began to emerge in the middle of his third paragraph. "We could safely leave the fate of Rosner's and Markowitz's historical scholarship to their community of academicians and historians if not for one discomforting fact", he argued. "The views of Rosner and Markowitz have become part of the passion play that we call silicosis litigation. Their participation in the litigation process thus raises the question of exactly what is the proper role of historians in litigation." He contended that "although a decade has elapsed since ... Daubert, trial courts have yet to address reliability challenges to historians and their opinions."18 All this despite the fact that at that time each of us had appeared on the stand in only one case since the publication of Deadly dust in 1991.

While our book on silicosis preceded our experience with the legal system, our next book on industrial pollution grew out of another law case. In 1996 we were called by two lawyers from the City of New York Law Department. The city's lawyers asked if we would visit them at their offices in lower Manhattan. It appeared that the city had been sued by some families whose children had been damaged by lead contained in the paint of some of the city's public housing. The city, in turn, had begun a suit against the lead pigment industry claiming that the industry bore some responsibility for damages to these children. In the process of seven years of the suit, the city had accumulated a moderate-sized roomful of documents that were largely drawn from the Lead Industries Association (LIA), the trade association for lead paint and other manufacturers of lead-bearing products. The city's lawyers wanted us to go through these hundreds of thousands of pages that had been accumulated and, using our expertise as historians, tell them what was in them.

They had contacted us because we had published an article on lead poisoning in the American Journal of Public Health in 1985. In that article we traced the history of the controversies around lead poisoning due to automobile exhaust. Coming as it did as the Environmental Protection Administration was determining whether or not to demand that the industry remove lead from gasoline once and for all, the article caused a bit of a stir in the public health community, even provoking an editorial from the Journal apologizing for its role nearly fifty years before in creating such a public health tragedy. ${ }^{19}$

\footnotetext{
${ }^{17}$ Nathan A Schachtman, 'On deadly dust and histrionic historians: preliminary thoughts of history and historians as expert witnesses in products liability cases', Mealey's Litigation Report: Silica, vol. 2, no. 3 (King of Prussia, Pa., LexisNexis, 2003), p. 1.

18 Ibid., pp. 1-6.
}

\footnotetext{
${ }^{19}$ David Rosner and Gerald Markowitz, “"A gift of God"?: the public health controversy over leaded gasoline during the 1920s', Am. J. Public Health, 1985, 75: 344-52; editorial, 'One man's meat, another man's poison: two chapters in the history of public health', Am. J. Pub. Health, 1985, 74: 338-40.
} 


\section{David Rosner and Gerald Markowitz}

We were retained by the New York City Law Department to evaluate the material they had received through the discovery phase of the trial and, with the aid of two Columbia students, we organized the material, and wrote an affidavit for the court about what we had found. From our work in the archives of the City's Law Department came the first part of our book, Deceit and denial: the deadly politics of industrial pollution. ${ }^{20}$ This book, an analysis of the role of industry in creating a public health tragedy, would not have been possible without the law cases which made accessible literally hundreds of thousands of pages of company documents. In fact, without the cases, historians would never have seen internal memos and minutes of meetings in which the company representatives from the Dutch Boy or Sherwin Williams companies discussed the dangers of leaded paint to children as early as 1930. Nor would we have been able to learn of marketing campaigns that claimed that lead paint was safe and sanitary and useful on children's walls, furniture and the like. This trove of documents revealed through the lawsuits allowed us to write a history that was based upon internal documents never before seen and it certainly gave us a new perspective.

The long affidavit became part of the New York City case and was quickly integrated into numerous other legal actions that began around the country. By the end of 2002, the cities of Chicago, New York, San Francisco, St Louis, Milwaukee and others had begun cases, some of which were quickly dismissed by judges, some of which have been allowed to go forward. In Rhode Island, the State Attorney General brought the first state action against the lead industry for having knowingly created a public nuisance in the form of lead paint on the walls of up to 80 per cent of the state's housing, thereby putting thousands of children in the state at risk of developing lead poisoning. This particular case gained national attention, with articles quoting our work appearing in Barron's, Newsweek, the New York Times, the Wall Street Journal, and elsewhere. In that case, we were each on the stand for six days, most of the time under cross-examination. Headlines in the local newspaper told that story: 'Lawyer, Historian, Spar over Lead Paint', 'Lead Paint Historian Testifies for 3rd Day', 'Paint Lawyers Work to Discredit Historian'. The trial was intense, but it provided the jury with the opportunity to see with their own eyes documents that told of the knowledge of the industry regarding childhood lead poisoning going back a century. The power of the documents was impressive and the jury found for the state, ultimately ordering the lead pigment manufacturers to "abate" the lead hazard throughout the state. ${ }^{21}$ That verdict was challenged by the lead industry but the judge rejected the defence's plea to overturn the verdict, writing a 197-page decision in which he often referred to the historical record that we presented at the trial. The potential liability for cleaning up the state of Rhode Island is immense as estimates of costs range from $\$ 1$ to $\$ 4$ billion. ${ }^{22}$ Recently, the Rhode Island Supreme Court overturned the verdict.

\footnotetext{
${ }^{20}$ Markowitz and Rosner, op. cit., note 3 above.

${ }^{21}$ Peter Lord, 'Judge refuses to overthrow lead paint conviction', Providence Journal, 27 Feb. 2007, p. A-1-6.

${ }^{22}$ Immediately after the case was settled the stock market responded to the verdict by forcing Sherwin Williams stock to plunge and Business Week announced that 'Costs of lead clean-up soar'. While the legal manoeuvering by the industry to delay the
}

jury verdict continues, Bloomberg.Com announced that in light of the Rhode Island decision the Attorney General in Ohio has initiated a similar suit. Michelle Smith, 'Estimates of lead clean-up soar', Business Week Online, 26 March 2007; Jef Feeley, 'Sherwin Williams, DuPont sued by Ohio Lead Paint', Bloomberg.Com, http://www.bloomberg. com/apps/news?pid=email_en $\&$ refer $=\&$ sid $=$ aQb5ogfWCWQk (accessed 27 Nov. 2008). 


\section{The Trials and Tribulations of Two Historians}

The second part of the book detailed records we went through regarding vinyl chloride monomer and the knowledge of the industry. It was this portion of the book that taught us a big lesson which we are only now beginning to analyse and understand. In about 1998 we were asked if we would be willing to take a look at an enormous store of company documents from the chemical industry that had been turned over during the course of an on-going lawsuit concerning a vinyl chloride worker dying from angiosarcoma of the liver. Angiosarcoma of the liver is extremely rare, occurring in as few as two dozen people in the United States in any given year. We were asked by the plaintiff's lawyers to help them evaluate what was in this store of materials and whether or not there was reason to believe that the chemical industry had acted badly with regard to their workers' safety. We travelled to Lake Charles, Louisiana, where the records were stored in a split level house in a desolate part of town and began a process that resulted in a 300-page timeline of knowledge and activities by the Manufacturing Chemists Association ([MCA] now the American Chemistry Council) that has become the basis for a number of lawsuits against the industry.

Again, the book Deceit and denial that details these two case studies received wonderful praise from the scholarly community, with reviews in Science, JAMA, the New England Journal of Medicine, the Lancet, and New Scientist, as well as the top historical journals with the major review journal of the field calling it "nearly flawless". ${ }^{23}$ Anthony Robbins, the former Director of NIOSH in the 1970s, gave similar praise, saying that despite his role as an "insider" during the decade and despite the fact that he believed he had "been well informed about what had happened in the struggle to regulate vinyl chloride", he learned an enormous amount from our book. "How little I knew!" he said. "How little I understood about industry's efforts to manipulate the debate and influence the regulatory outcomes. For these classic cases, lead and vinyl chloride, this book tells much more than I knew, perhaps close to the whole story." 24

In addition to the timeline and the book, our documents became part of a Bill Moyers PBS special called Trade secrets which displayed the documents we had uncovered, featuring us as talking heads for the first hour. It exposed the chemical industry for having covered up and deceived the public about its knowledge of the dangers of vinyl chloride and made a link with other products of the chemical industry. Moyers won an Emmy for investigative journalism for the film. Another documentary, Blue vinyl by Judith Helfand and Daniel Gold, also took the industry to task, using some of the material we uncovered. It too won awards at Sundance and was shown nationwide on the television station HBO.

\section{Reaction by Industry Lawyers}

Imagine our sense of pride. The book had been praised by the scholarly community for its rigour and scholarship; major documentary filmmakers and social commentators like Bill Moyers had acclaimed the book and used its material; other filmmakers were telling

\footnotetext{
${ }^{23}$ See, http://www.deceitanddenial.org/, the website Merlin Chowkwunyun established for us. On it are numerous reviews, our timeline, Scranton's attack and our defence. Also, we have posted links to thousands of pages of documents that
}

form the core of the research for two chapters of the book.

${ }^{24}$ Review of Deceit and denial by Anthony Robbins, Journal of Public Health Policy, 2003, 24 (3/4): 492-4, p. 493. 


\section{David Rosner and Gerald Markowitz}

the story of vinyl on HBO; we won a number of awards from professional associations and community groups for our work; we were invited throughout the country to speak about the book.

All was going well until one day when we were working in David's office at Columbia University's Mailman School of Public Health, and the phone rang. It was from the University of California Press representative who told us that the Press and the Milbank Memorial Fund which had co-published the book, had received a subpoena to produce all their documents related to the publication of Deceit and denial, including all correspondence, peer reviewers' reports, e-mails, and memos between the Press and the Fund. Shortly after, we received another call from a colleague who had been subpoenaed to appear for deposition because he had been one of the peer reviewers of our book for the University of California Press. He was in a bit of a panic as he never before had received a document requiring him to bring all data related to his review, all drafts, all correspondence, etc., and to be questioned by lawyers. The next day and in the days following what had appeared to be an oddity turned into a major crisis for us. In all, five of the eight reviewers of the original manuscript received subpoenas and were forced to testify at depositions regarding the peer review process, their evaluations and even their personal and professional relationships with us. But the final indignity came when we received via e-mail a 41-page attack on us written by another historian, Philip Scranton, a professor of history at Rutgers, across the river in Camden, New Jersey. This document was unlike anything we had ever seen before: it was a scathing attack, not a review, that argued we had been guilty of ethical misconduct, violating virtually every code of the American historical profession. Its purpose was to disqualify Jerry from testifying in a vinyl chloride case. Unbelievable on its face, we were quite shocked and wondered what to do. It was clear we had to respond, but to whom?

For the next few days we wrote our response which, we believe, reveals to any reader exactly where Scranton was absolutely wrong and inaccurate. It was clear that much of the document was written for a legal purpose, not any historical scholarly community. He spent a number of pages arguing about whether we could use the word "industry" when describing the memos, letters, and minutes of meetings at which member companies of the MCA discussed how to deceive the government. He worried about "evidentiary proof", and accused us of having inadequate documentation despite the fact that our 300-page book was accompanied by 81 pages of footnotes. He seemed to torture the AHA (American Historical Association) Statement of Professional Conduct in an attempt to show that we were transcending sacred historical principles. In toto it was a hollow statement but one which might sound impressive just by its weight to anyone not familiar with our text and our data.

Fortuitously, the academic and scholarly world picked up on the larger issues involved in our case, pointing out the threat to academic freedom and peer review that such actions entailed. "Like others contacted by The Chronicle, Ms. Withey [the Director of University of California Press] says she has never heard of another example of reviewers being subpoenaed. 'It's a disturbing situation,' she says. 'It's really pretty sleazy on their 


\section{The Trials and Tribulations of Two Historians}

part." 25 An article by Jon Wiener in The Nation magazine was even more detailed and more damning of the industry's use of Scranton and the abuse of the peer review process. It began by stating:

Twenty of the biggest chemical companies in the United States have launched a campaign to discredit two historians who have studied the industry's efforts to conceal links between their products and cancer. In an unprecedented move, attorneys for Dow, Monsanto, Goodrich, Goodyear, Union Carbide and others have subpoenaed and deposed five academics who recommended that the University of California Press publish the book Deceit and Denial: The Deadly Politics of Industrial Pollution, by Gerald Markowitz and David Rosner.

Much of the article centred on the industry's use of Philip Scranton and the stakes involved that led the industry to try to discredit us and to undermine the peer review process.

The reasons for the companies' actions are not hard to find: They face potentially massive liability claims on the order of the tobacco litigation if cancer is linked to vinyl chloride-based consumer products such as hairspray. The stakes are high also for publishers of controversial books, and for historians who write them, because when authors are charged with ethical violations and manuscript readers are subpoenaed, that has a chilling effect. The stakes are highest for the public, because this dispute centers on access to information about cancer-causing chemicals in consumer products.

Weiner pointed out that "Although Scranton is serving in this case as an expert witness for the chemical companies, he's not an expert on cancer-causing chemicals", while "Markowitz, in contrast, is a genuine expert on the central issue in the case: the question of what the chemical companies knew, and when they knew it". Weiner went on to evaluate the reliability of Scranton's claims on behalf of the industry that our work violated the AHA statement on standards. He "asked the vice president for research of the AHA, Roy Rosenzweig, Distinguished Professor of History at George Mason University", who responded: "I've read the AHA Statement on Standards ... I see nothing in Markowitz and Rosner's book that's a violation of the AHA Standards. In my opinion, the book represents the highest standards of the history profession. Scranton should be embarrassed to make the claim that there's an ethical violation here-as opposed to the claim that he disagrees with their interpretation.",26

Weiner also drew attention to the similarities between Scranton's attack on us and the parallel "arguments made by the tobacco and lead companies and their attorneys in those historic liability lawsuits, arguments that have been identified by Stanford historian Robert Proctor, writing in The Lancet, one of the leading medical journals in the world". He summarized Proctor's article saying,

The generic arguments go something like this: Although historians have found evidence that industries were aware of the danger posed by their products, that evidence was not definitive; because they had "no proof," they had no obligation to act to protect the health of workers or the public; standards of corporate morality and openness have become stronger only recently, so it's "unfair"

\footnotetext{
${ }^{25}$ Lila Guterman, 'Peer reviewers are subpoenaed in cancer lawsuit against chemical companies', Chronicle of Higher Education, 19 Nov. 2004.
}

\footnotetext{
${ }^{26}$ Jon Wiener, 'Cancer, chemicals and history', The Nation, 7 Feb. 2005, pp. 1-3, http://www. thenation.com/doc/20050207/wiener.
} 


\section{David Rosner and Gerald Markowitz}

to apply today's standards to past conduct; and of course there's always the argument that the historians who claim to have found evidence of corporate misconduct are "biased."27

Throughout the United States, toxic cases are leading companies and their lawyers to seek out their own historians to argue that companies bear no responsibility for a host of conditions that appear associated with exposure to implants, asbestos, pharmaceuticals and the like. Tobacco, mining, paint, plastics and chemical companies have begun to hire historians to use their skills to obscure and to confuse the historical record about responsibility, knowledge and risk. In some sense, the role of historians of medicine and science has been to create confusion rather than to illuminate history. Some historians have earned literally millions of dollars defending the tobacco and lead companies during litigation; others have earned equally large amounts preparing defences of industries ranging from lead paint manufacturing to plastics and environmental pollution. ${ }^{28}$

While many historians have decided to enter the fray on behalf of injured parties, others have been hired by the tobacco, lead and other industries as "experts" to defend the actions of a variety of companies. Rather than using their skills to try to clarify the historical record, however, these historians have often sought to "contextualize" past unseemly activities in which tobacco, lead and other toxins were marketed despite industry knowledge of their dangers.

How then can we begin to evaluate the place of the historian in the courtroom? First, we might ask what the basis for his or her testimony is. Schachtman argues that whatever the historian can do the lawyer can do better, or at least as well. ${ }^{29}$ In his depiction, the historian is little more than the presenter of abstracted data which he calls "facts"- dates, documents, statements, events. As such there is little reason for considering them "experts". Of course he begins with a model of historical training that ignores the seven years of graduate training in historical research methodology, dissertation writing, oral exams, and doctoral seminars, and he presents a model of history that in and of itself is naive. The historian's skills are bound up in an ability to contextualize, to weave together and make sense out of many discreet pieces of information that, alone, usually contain ambiguous and unintelligible random information. By placing them in a broader historical context and drawing from a variety of sources both directly and indirectly related to the subject, the historian takes what may seem to be idiosyncratic events and makes them intelligible, part of a continuous stream of information that reveals infinitely more than any one document can possibly reveal. Hence, the skilled historian can take many documents and tie them together or take a single document and make it intelligible. Obviously, recent twentieth-century historians often have a huge store of information to work with, summarize and contextualize, while a medievalist might have only a single primary document such as a illuminated manuscript with which to work. But both have the ability to draw out meaning whether through the words, pictures or sounds in the document itself or from the events and literature that it speaks to.

${ }^{27}$ Ibid., p. 3.

${ }^{28}$ Robert Proctor, 'Should historians be working

${ }^{29}$ Schachtman, op. cit., note 17 above, p. 1. for the tobacco industry?', Lancet, April 10, 2004,

363: $1174-5$. 


\section{The Trials and Tribulations of Two Historians}

Attorneys, as often as not, see the historical record very differently, attempting to find either discreet documents that "tell the whole story"-_"smoking guns" so to speak-that reveal the true intent or knowledge base of individuals. We've been asked for "one or a handful of documents that tells it all" to which we have to explain the complexity of historical narratives. Certainly there are individual documents that can and do stand on their own, but more often than not it is the accretion of information, the development of knowledge, the sequential accumulation of meetings, minutes, advertisements, scientific or medical articles, speeches and more that demand explanation by historians trained in piecing together necessarily incomplete historical materials.

Historians are sensitive to the incomplete nature of the historical record. Records are, from the historians' perspective, never complete. This does not mean they can never reach conclusions but it does mean that within limits there are reasonable, differing ways to interpret data. We could not say that someone "really knew" that he or she was making false statements, misleading the public, lying to others for we cannot give a lie detection test to the historical figure. Did a person "knowingly" do something wrong? For the historians the accumulation of data, of information, allows limited statements: we can "know" that an individual or company representatives were present at a string of meetings when childhood lead poisoning was discussed but were they paying attention? Were they out of the room when these issues were debated? What was going through their minds when they interjected a statement into the record? Were they completely out to lunch except when their words are specifically mentioned in the transcript of a meeting, or were they full participants? For the lawyer, such acknowledgement of gaps in the historical record amounts to uncertainty and is useful in creating doubt and discontinuity. The very complexity of history often provides openings to create ambiguity or even to undermine the historians' craft. A skilled lawyer can present the world as a series of discrete events and, when interested in undermining testimony, often disconnect, rather than connect, the dots. The ambiguity or limited scope of a particular piece of information will become the means of dividing and decontextualizing the historical record, leaving the argument incomprehensible, disassembled, in pieces.

There are many examples that we could mention but we will briefly review the give and take in one of the depositions that we gave in preparation of the Rhode Island lead suit. During the deposition David had presented a listing of the times in the 1930s that the Lead Industries Association had talked about lead poisoning and childhood lead poisoning in particular. Coming after many hours of discussion of the early twentieth-century medical literature on childhood lead poisoning (from nibbling on lead painted toys, cribs, woodwork and other surfaces in the home that preceded the 1930s) and numerous mentions in trade and other publications of lead poisoning (among workers, children working in lead pigment manufacturing plants), movements to ban the use of lead by twenty-one countries, and other instances where lead pigment was identified as a "deadly, cumulative poison" that should be banned or limited to outside use, the statements in the industry association minutes seemed clear enough. Those collecting data, providing information to the public about lead, systematically following all that affected the market for their product, could not reasonably claim not to know about the evidence pouring out. We could understand the industry trade association minutes, which proclaimed that lead 


\section{David Rosner and Gerald Markowitz}

poisoning consumed immense amounts of the association's time, as meaning that they were "aware" of the issue when the association's annual meetings often reported on "Lead Poisoning".

From our perspective there was little question that we could connect the dots, most of which were as large as giant stains. But this was not the case as the lawyer for one of the companies sought to separate each statement, to identify the gaps in knowledge rather than the continuities. Picking up on the fact that there were a number of years where the annual meeting minutes spoke generally of lead poisoning, without identifying "childhood" lead poisoning in particular, the lawyer asked David whether or not it was possible that the industry just "wasn't aware" or "didn't know" that childhood lead poisoning was an issue in those years? Was it not possible that they thought the issue "resolved?"

The historian is also sometimes asked if he or she can "really know what's in a person's mind". One lawyer, for example, faced by letters that said that a physician was visited by the trade association head to dissuade him of his belief that lead was poisoning children in Baltimore, wanted David to "admit" that the head of the trade association might really have "believed" that lead was not a problem:

"Do you have any evidence that Mr. Wormser [the Secretary of the trade association] was other than sincere in his stated views that lead toxicity was exaggerated in the public press?" he asked David.

"Other than sincere?" David quizzically asked.

"Yes. Do you have any evidence that he did not believe the things he was saying?"

How does one answer that question? "Well, I'm certainly not in his mind," David began, but "it seems very odd that a man who lived through this entire period, and who had access to the kind of information he had access to, and who continually sought to calm apprehension and had enormous amounts of information surrounding him, did not suspect that there might be a problem here." But did David "know" that he "knew", understood, believed differently? David had to "admit" that "whether he's sincere, I just don't know". 30 Regarding what its main spokesman knew, David simply responded, "I have no idea how to get to the soul of that man." 31

\section{The Epistemological Question of What is Knowledge?}

When faced by evidence that industry representatives tried to influence doctors to change their diagnoses, and legislators to stop regulations that might inhibit the use of lead paint, or prod school and other officials into buying lead paint, a lawyer might try to argue that despite the evidence, there was no reason to suspect that the industry representative was "successful" in changing behaviour. David was specifically asked:

"Do you have any evidence of any doctor being visited who withheld information or changed their opinion?"

\footnotetext{
${ }^{30}$ State of Rhode Island, Providence, Sc, Docket No. 99-5226, State of Rhode Island, by and through Patrick Lynch, Attorney General, Plaintiff vs Lead Industries Association, Inc., et al., Defendants,
}

volume Iii videotaped deposition of David Rosner, Law Offices of Arnold \& Porter, New York, July 6, 2005.

31 Ibid. 


\section{The Trials and Tribulations of Two Historians}

"No," he answered, "I don't have any writing that says 'I changed my opinions on the basis of this person's decision or this person's visit."”

"You also don't have any LIA document indicating that they changed anyone's mind, do you?" David was pressed.

"Well, we have a number of LIA documents in which Wormser claims that he's changed opinions of numerous people, from state legislators, to people writing warning labels, to physicians who he felt visits to were very profitable ...", David responded. But did David "know" he changed peoples' minds? No. "I don't have any writing that says 'I changed my opinions on the basis of this person's decision or this person's visit'."

The point of the exchange was to get David to state that the actions of the industry, no matter how reprehensible, may not have had any effect whatsoever and the historical evidence of their efforts to shape the outcome through visits to doctors, legislators, administrators and the public at large through advertising, was irrelevant to the legal proceedings. Further, the questioning was aimed at undermining any affirmative answer David might give regarding intent or understanding.

The ambiguity of the historical record can work to the advantage of industries not only by seeking to undermine historians for plaintiffs. In fact, instances of historians who emphasize the difficulties of making historical judgments abound. Philip Scranton, for example, the historian of business and technology at Rutgers, has given a deposition in asbestos litigation in which he literally argues that knowledge itself is difficult to discern, if it is ever attainable. He was hired by lawyers for the asbestos industry to write a timeline of important events from the 1930s through the 1960s. In nine pages, he outlined an arbitrary set of events in the history of technology that he deemed worthy of inclusion, none of which mentioned asbestos or asbestos-related disease. One can only suppose that the purpose of including him as a witness in a case regarding asbestos exposure was simply to illustrate that there were many things on people's minds other than disease in the period between the Depression and the 1960s.

But the questioning by plaintiffs' lawyers took an interesting turn. Scranton was asked at the deposition whether he had an opinion about whether or not a company should have warned workers about knowledge regarding the dangers of asbestos exposure in the 1930 s, to which he gave a long answer regarding what it meant to "know" something in science. Before definitive statements could be made, he argued, information had to be tested, confirmed, retested, and subjected to years of examination. The implication was that, even if the company said something in 1936 that indicated that they "understood" that asbestos could injure the workforce, this was something different from "knowing" it was dangerous and, therefore, there was no responsibility on the company to inform the workers of information that it was not sure of: "The problem with the question," Scranton began,

is the ambiguity about what "knowing" means. And let me try to provide you with something, at least from my professional background, that may explain to you why it's difficult for me to answer this question. In the history of science and technology, there are multiple stages of knowing before action in sort of a grand sense can be taken. You can know, for example, that there's a problem. And when a problem is identified, multiple participants will assess the severity of the problem, trying to figure out how bad it is. They'll disagree. And after a period of time, some kind of consensus 


\section{David Rosner and Gerald Markowitz}

comes about the challenges this problem presents. And then there's a problem that has to be addressed about how to measure it, and that goes through a series of discussions among scientists or technologists and engineers. And there are a lot of proposals about how to measure the issue that's at hand. And after some work on that front and some agreement or at least debate about terms of measurements, scientists and engineers and technologists focus on what will fix the problem, and that involves a period of work because it's not obvious, often, what will fix the problem, and there are a whole bunch of proposals for that. And then after another period of time, some kind of consensus is reached on figuring out how to get the problem fixed. All of those are stages of knowing, one after another. ${ }^{32}$

Such a process can take years, even decades, and, apparently, in the intervening period of time there was no responsibility to warn until all the facts were in, all information was available and widely known, and no scintilla of doubt existed about causation. Despite the obvious problem with his argument - that industry has no responsibility to warn its workforce or consumers until the bodies pile up and scientists have reached total consensus through Popperian methodologies-Scranton's historical argument certainly played a part in attaining the industry's goals of introducing uncertainty.

It appears that the legal strategies of the law firms have followed a common pattern and a common rationale. In what Proctor has called "agnatology", industry has created a new "science" for the creation of doubt and ignorance about its actions in the past and historians have played a significant role. ${ }^{33}$ Lawyers for the tobacco, lead, asbestos industries, among others, appear to have adopted a few basic techniques to waylay historical evidence that shows they were aware of the dangers of their products. In general, they have argued that:

Whatever the evidence of knowledge within industries of the dangers of a product that existed in the past, there was insufficient information available for there to be definitive proof of real danger.

Therefore, there was always a need for more research before doubt could be eliminated and those who questioned that a material was dangerous indicated that there was a "controversy" about whether or not it was.

Causation is extremely difficult to prove and requires years, if not decades, of careful experimentation and observation before "controversy" about the sources of disease could cease.

Hence, without certainty, and in the context of any on-going controversy about the danger of a product or substance, there was little or no obligation on the part of industries to act to remove their product from the market or to lower exposures to toxic materials within the factory.

\footnotetext{
${ }^{32}$ In the Circuit Court of Kanawha County, West Virginia. In Re: Asbestos Personal Civil Action Injury Litigation Mass No. 02-C-9004 Litigation Panel Deposition Transcript of Philip Scranton, PhD
}

Deposition Date: September 18, 2002, Wednesday, 10:10 a.m.

${ }^{33}$ Proctor, op. cit., note 28 above. 


\section{The Trials and Tribulations of Two Historians}

Industry's argument about our book and testimony closely parallels this structure:

There was always a reason to gather more and more information before telling government, workers or the public of the possibility that a substance was carcinogenic in humans at low doses.

Science is a slow, cumulative process that demands that information about danger should not be revealed until scientific proof exists and after "controversy" over that proof is laid to rest.

Industry always had valid reason to doubt the accuracy of any finding of carcinogenesis.

History is a complex ("messy," in Proctor's discussion) process in which clarity is rare and confusion the norm.

Historians who draw conclusions that indicate industry's malfeasance are sloppy, simplistic or biased.

"Objectivity" in historical analysis requires that equal weight of plausibility be provided to all sides in an argument and that no judgments should be made.

"Objectivity" requires that even disinformation, including all self-serving statements, be presented as legitimate.

Every conflicting piece of information should be reported, irrespective of its importance to the historical questions being asked.

Incomplete knowledge is equivalent to controversy about that knowledge.

One should ignore evidence of responsibility in favour of evidence of ambiguity or innocence.

Positive peer reviews or post-publication reviews are invalid unless the reviewers have read all the primary documents.

Any sign of "presentism" is bad, except when it exonerates the industry.

When all else fails quibble endlessly about adjectives, nouns or adverbs used to describe or summarize corporate behaviour.

Industries are playing on historians' professional propensity to see complexity and ambiguity in human events; but here they are using our well-honed skills as historians to promote confusion in order to obscure their own culpability in legal suits.

The growing concerns about the price we pay in health and well being for our unrestrained industrial and post-industrial society has created new arenas in which history will play a growing and important role. Especially as the Bush administration undercut the regulatory agencies of Occupational Safety and Health Administration, and Mine Safety and Health Administration, Environmental Protection Agency and others that have since the 1970s ameliorated some of the worst conditions affecting workers and consumers alike, we can expect more and more toxic cases to be brought to the courts rather than to the professionals in these agencies. In this context, it is important for us to recognize 


\section{David Rosner and Gerald Markowitz}

the growing demand for our skills. We may be dragged kicking and screaming into moral dilemmas where we are forced to confront the question: what are the boundaries of our involvement in public disputes? In part, this will be an unwelcome circumstance for us. Yet, we would argue that we owe society a great deal and we owe those who are often without a voice a great deal more. We believe that the demands from the legal system will force us to crystallize our sense of purpose and the humanistic traditions that lend legitimacy to our field. A greater relevance and involvement of historians will force us to define what is "good" history, both methodologically as well as morally. 